\title{
Does the EU Funding Increase Competitiveness of Firms by Supporting Organisational Changes?
}

\author{
- Martinez Felipe, Potluka Oto
}

\begin{abstract}
Competitive firms with a good economic performance contribute to social development and quality of life. Countries and regions support competitiveness of firms through public policies and public funds. The research concerns question whether financial support from public funds actually helped to increase competitiveness in firms through organisational changes. This paper explores the relationship between competitiveness of firms (measured by sales divided by employment) with organisational structure changes and the amount of financial resources from the EU Structural Funds. The data were collected from the Czech Statistical Office and a survey among Czech firms. The estimates provide us with conclusion that only the European Social Funds assistance had a positive effect on productivity, but not organisational changes in firms.
\end{abstract}

Keywords: Competitiveness, Productivity, Organisational Change, EU funding.

JEL Classification: L22, M11, D23

\section{INTRODUCTION}

Competitiveness is an important factor of the social development (Iordan et. al., 2012). The ability of firms to uniquely combine production factors highly contributes to the competitiveness of countries and regions (Porter, 2008). A high level of competitiveness creates wealth (Wilhelm \& Wilhelm, 2011). This enables societies to live in satisfactory economic, political and social conditions (Porter, 2008).

Individual countries and regions differ substantially in their competitiveness (World Economic Forum, 2013, 2014). This competitiveness heterogeneity motivates researchers to find reliable explanations relating to development policies. In general, the research explores the macroeconomic policies that influence the success of particular countries and regions. Moreover, the competitiveness has a microeconomic character under the premise that the microeconomic performance of firms contributes to it (Martins \& Solé, 2013). Firms' high performance creates wealth through added value in goods and services (Porter, 2008). The macroeconomic policies are important to create the framework for competitiveness (Huggins et. al, 2014). From this point of view, it is important to cope with the causes of the competitiveness at the firms' level, which is also the case of our research.

The mechanisms implemented by firms to achieve success on the market are innovation (Rajnoha \& Lorincová, 2015, Audretsch et. al., 2014, Triguero et. al., 2014), export orientation (Mishra \& Jaiswal, 2012, Cheptea et. al., 2014), low price strategies (Dobson \& Piga. 2013) and specialization (Micic et. al., 2014). In addition, clusters, collaboration and local market focus comple- 
ment the value-creation in firms (McDonald, 2014, Jensen \& Petersen, 2014, Šebestová, 2010). The combination of all these pillars, production factors or approaches creates the competitive environment in which firms perform (Huang \& Rice, 2013). Therefore, the macroeconomic consequence of competitiveness is the result of the microeconomic performance. Country and regional competitiveness has a strong bottom-up component while top-down competitiveness policies facilitate the firms' performance (Porter, 2008, Jungwirth \& Müller, 2014).

Move towards higher competitiveness (e.g. through innovation or change of production factors' combination) brings necessity to reorganise production and change organisation's structure. Organisational structure and organisation of processes belong among important issues of production factors utilisation and thus the key factors influencing a firm's performance. Organisational development to better performance is only possible with organisational changes. It is impossible to achieve improved results by performing the same activities (Mintzberg, 1980). A change in an organisational structure is a good measurement of an organisational change. Hendriks (2006) compiles different definitions of organisational structure. He simplifies them by standing out the importance of differentiation and integration within the structure. Moreover, the desire to become unique and have an unrepeatable combination of production factors to excel competitiveness is only possible by a flexible and dynamic organisational structure (Sopelana et. al., 2014). Thus, there is an important contribution of organisational changes to the dynamic development of competitiveness of firms.

There are several arguments with regards to microeconomics of competitiveness. One of them is a low-cost labour force. This is a major factor to influence a firms' competitiveness based on their impact on prices. However, the simple rationality of low-price strategy presents uncertainties (Ariely, 2009). Then, academics and policy-makers focus on productivity as a more complex decisive factor to analyse competitiveness (Delgado et al., 2012). In our case, productivity is selected as a competitiveness indicator similarly to Hudrlíková and Vltavská (2013).

Prices change for several reasons. If changes are happening at neighbouring markets, the ripple effect (see Jones \& Leishman, 2006) changes prices due to the connection with those markets. Then, long-term competitiveness comprises the price but also other factors and their unique arrangement. The unique combination of production factors proves to be the fundamental nature of a competitive firm.

"Access to labour, capital, and natural resources no longer determines prosperity, because these have become widely accessible. Rather, competitiveness arises from the productivity with which firms in a location can use inputs to produce valuable goods and services. The productivity and prosperity possible in a given location depend not on what industries its firms compete in, but on how they compete" (Porter, 2008). Thus, the economic performance at micro-level and macro-economic strategies are interlinked.

One of the objectives of the strategy Europe 2020 is to improve competitiveness of the European Union through the competitiveness of firms. The European Union linked this strategic plan with the EU Cohesion Policy which is a huge investment done by the European Regional Development Fund (ERDF) and the European Social Fund (ESF) in compliance with this strategy. Not only does the EU Cohesion Policy command enormous financial resources of 453,2 bn. EUR (EC, 2015), but the EU is also very willing to support firms from this source. This massive 
investment in the EU Cohesion Policy enables firms to play an important role in making the EU more competitive and to improve their overall capacities. To have a positive impact, the aid must be used on specific activities within a programme. Moreover, the use of this money must have a positive effect in society (satisfactory economic, political and social conditions (Porter, 2008). This article explores the influence that the EU Structural Funds has on a firms' competitiveness.

Under this frame, we suppose that if the firm changes the organisational structure and it obtains financial assistance, then its productivity increases. The research aims to answer the questions whether the Structural Funds' assistance helped to increase productivity in firms through organisational changes and whether does the combination of organisational structure change and financial subsidy increase productivity. These research questions analyse two input factors: organisational structure changes and financial aid award. The research questions review the influence of both inputs into productivity, which is used as a proxy variable for competitiveness.

The answers to these questions contribute to an understanding of the influence of the macroeconomic policies on competitiveness and wealth. It will also support or reject the arguments to continue this kind of assistance for firms. Moreover, it explores the possibilities to improve the effectiveness of these investments by proposing the organisational structure as an important element to measure aid implementation success.

The innovation of this article lays in the combination of three variables: financial aid award, organisational structures changes and competitiveness. The article explores the relation among them.

The paper consists of five sections and is organised as follows. First is introduction to the competitiveness issue. Second, the organisational structure changes and competitiveness are discussed together with the EU Cohesion Policy assistance in firms. Then, explanation of the application of the scope of the public aid to firms follows. Data and methodology are described in the third section. Results with discussion are in the fourth section. The last section comprises of conclusions.

\section{ORGANISATIONAL STRUCTURE IN FIRMS AND SUPPORT TO COMPETITIVENESS}

This article explores the relationship between the organisational structure of firms and the support of EU funds for firm's competitiveness. This section defines and presents the relationship of organisational changes the EU funding and competitiveness.

\subsection{Organisational Structure Changes and Competitiveness}

Change is inevitable to achieve better economic performance. Every single goal, plan or objective to improve competitiveness is achievable as long as the organisation has the adequate structure (Corbett \& Angell, 2011, Chromjaková \& Rajnoha, 2012). Organisational theory and design present several models and approaches in this issue (Perrow, 1973, Davis \& Marquis, 2005, Hassard et. al, 2013). Moreover, there is a powerful principle that rules most of them: the structure follows the strategy (Chandler, 1962). 
Reasons to incite an organisational change usually arise from a strategy. Daft (2010) defines organisations as "social entities that are goal-directed, are designed as deliberately structured and coordinated activity systems, and are linked to the external environment". Goal-directed is the strategic component of the definition. The definition of organisation by McLean (2005) includes the "common pursuit or objective" and the definition of Miles and Snow (2003) comprises "both an articulated purpose and an established mechanism for achieving it". These definitions argue the existence of the organisation only if there is a goal, pursuit or purpose to achieve. Porter (2008) defines strategy as "the creation of a unique and valuable position, involving a different set of activities". From these definitions, it is possible to argue that the strategy is the goal or desirable future statement of the organisation. Therefore, it leads to competitiveness.

Organisational design comprises all the necessary activities to set up the different parts of the organisation in order to achieve the desirable goal (Robbins, 1990, Kates \& Galbraith, 2007). The procedure starts with the necessity of change. Usually, this necessity derives from an external change (i.e. crisis, new market, competitors, etc.). The output of the procedure is the organisational structure or the adequate arrangement of the organisational parts.

Usually, the formal specification, compilation and coordination of job tasks define the organisational structure (Sherman et al., 2007). The location of the formal power and authority is another element to define the organisational structure (Kates \& Galbraith, 2007). Moreover, the differentiation of the organisational parts and the clear and useful integration of them determine the structure (Hendriks, 2006). Any structural change provokes an effect on product/service market delivery. An organisational change planned in accordance with the strategy achieves a desirable effect. A firm with clear intensions to improve its competitiveness emphasises on "a unique and valuable" position on the market (Porter, 2008). This commitment with competitiveness improvement requires organisational changes.

Organisational change helps firms to achieve goals (Shirokova et. al., 2014). So, if a firm wants to be more competitive, then it has to restructure (Stojcic et. al., 2013). The absence of change leads to a long-term stagnation even in a short-term-successful firm. Some firms react to market changes. Other firms enter the market (Surdu \& Potecea, 2012). In any case, the expected result of changing the organisation is to achieve the desirable goals. The observation of the organisational structure provides evidence that the organisation has changed.

\subsection{EU Funding in Firms}

The EU Cohesion Policy is one of the main tools to implement the European Union policies. In general, the EU funding aims at improvement of the quality of life and wealth within and beyond the EU. The EU Cohesion Policy 2014-2020 aims toward the creation of growth and jobs, tackling climate change and energy dependency, and reducing poverty and social exclusion. One of the funding tools is the European Social Fund (hereafter ESF) which belongs to the European Structural \& Investment Funds. Specifically, the ESF aims at employment, social inclusion and good governance. This fund is managed in coordination between national and regional authorities.

For this research, we investigate the Operational Programme Human Resources and Employment (hereafter OP HRE). It is an operational programme funded by the ESF with the aim to 
reduce unemployment in the Czech Republic. It provides financial aid for projects which result in the securing of employment. The OP HRE comprises $€ 2.21$ billion budget. The ESF assigns to the operational programme $€ 1.88$ billion. The Czech Republic provides additional $€ 0.33$ billion to the programme. The total amount is close to the 7\% of all funds assigned from EU funds to the Czech Republic (MLSA, 2011).

OP HRE, support area 1.1., focuses on increasing the scale and effectiveness of the active employment policy and it also emphasises on supporting the competitiveness of enterprises and organisations. The specific activities comprise of the development of professional knowledge, competences and the improvement of the qualification of employees and employers together with the personnel management systems in firms (MLSA 2011). This area of support also focuses on modern management methods; conceptual human resource management and implementation of organisational changes.

There are several types of calls for proposals in the OP HRE in the support area 1.1. The difference relies on the instrument of the support. It can be support directly to firms or through professional associations and chambers. In essence, it is possible to define three types of calls in relation to this article. Those are the grant calls when a firm applies for the ESF assistance. In such a case, the successful applicant gets funding for training, human resources management, and for management of the project. The managing authority of the HRE OP arbitrarily determined the grant size between 1 million to 10 million CZK (40 000 to 400000 EUR). The second type concerns assistance in training. The Czech Labour Office is responsible for the management of a system project named "Educate yourself!". Firms apply for particular training in this project. The third group of calls concerns also the associations that provide training to firms. The third type of assistance is out of the scope of this research it will be also difficult to collect data from intermediaries (associations and training agencies).

Competitive firms understand the value of their employees (Saha et. al, 2011). To educate employees to achieve new duties is expensive (Čonkova, 2013), but it should pay off. Additionally, the retention of non-productive employees is against competitiveness (Gulski, 2011). Operational programmes such as the OP HRE contribute to firms' competitive strategy. Firms need the financial aid to educate employees in new business aspects in order to improve competitiveness. The new educated employees are the new suitable workforce (Horňáček \& Zelenková, 2014). This workforce should create and fulfil new structural needs for competitiveness. Then, the expected result of a financial aid is a more competitive firm which contributes to a wealthy society. These new structural needs are activities and jobs that presume an organisational change (Ramezan et. al, 2013).

\section{METHODOLOGY}

We explain data collection, data processing and methodologies used to answer research questions in two steps. First, we present data collected for the purpose of our research. Second, we introduce methods of the research. 


\subsection{Data}

Two data sources allow the development of the research. The first source is a survey. The second source of data comes from the Czech Statistical Office (CZSO). The collected data for this research includes limited firms and stock firms from the Czech Republic. Some of these firms applied for the ESF assistance and were awarded; some of the firms applied and were rejected; other firms did not even apply for support at all.

The data from the survey provides the input to solve the research question with regards to the organisational structure and financial aid awards. The survey was conducted during August and September 2012. It includes 1679 Czech firms surveyed by computer-assisted telephone interviewing (CAWI). The survey consists of 38 questions divided into five sections. First section relates to general questions. Second section is dedicated to human resources development in a firm. Third section aims to position of a firm on the market. Fourth and the largest part concerns applications and awards of subsidies by a firm. Fifth section contains questions on organisational issues in a firm.

For the purpose of this research, the part of organisational structure, organisational changes and subsidies of the Structural Funds is designed specifically to collect specific information on influence of organisational changes and subsidies on competitiveness.

Tab. 1 - Grant calls and system project call for training in firms. Source: Survey, own calculations

\begin{tabular}{|c|c|c|c|c|}
\hline & \multicolumn{2}{|c|}{ Grant applicants } & \multicolumn{2}{c|}{ Educate yourself! applicants } \\
\hline $\begin{array}{c}\text { Have you applied for the } \\
\text { ESF assistance? What was } \\
\text { the result? }\end{array}$ & Frequency & Percent & Frequency & Percent \\
\hline Yes, supported & 441 & 27,3 & 503 & 31,1 \\
\hline Yes, rejected & 93 & 5,8 & 37 & 2,3 \\
\hline No & 1079 & 66,9 & 1079 & 66,6 \\
\hline Total & 1613 & 100,0 & 1619 & 100,0 \\
\hline
\end{tabular}

The CZSO in close cooperation with the Ministry of Labour and Social Affairs has provided us specific data about firms. This is data on Sales, Income and the Number of Employees from 2006 to 2011 collected from the balance sheets. It enables to cover the period before the economic crisis as well as during the crisis when firms have to react to economic situation (e.g. by changes in organisational structure). It also covers both pre-assistance and implementation periods of the ESF projects in firms. For the purpose of privacy, CZSO provides the dataset to the Ministry which anonymised the dataset. Thus, it is not possible to identify individual firms in the dataset, but it is still possible to conduct statistical analysis.

The data about productivity derives from the CZSO. A proxy variable for productivity is used as sales divided by the number of employees (see discussion on correlation between competitiveness and labour productivity in Hudrlíková \& Vltavská 2013). A change of productivity within the period of $2008-2011$ has been used as: 
The data sample is large enough for the purpose of the statistical representativeness. At the end of 2013, there were 681347 firms (not including 1784155 individual entrepreneurs) in the Czech Republic (CZSO, 2014). The data sample size with 1679 responses fits the usual statistical requirements, i.e. $5 \%$ of margin of error and $95 \%$ of confidence level.

A smaller sample size is used for the analysis. It is caused by the non-response of respondents to some questions. For example, there are 1679 firms in the data sample, but only 1613 of them responded to the question concerning their activity in grant applications (see table 1). The combination of the data from the survey with the data on sales and employment decreases again the sample size (all sizes are reported together with an analysis).

Since the economic crisis began later in the Czech Republic compared with Western countries in Europe, this dataset enables the research to explore the situation in Czech firms before (2008) and during the economic crisis $(2009$ - 2011) as the call for proposals were aimed to help firms to sustain the crisis (for example see MLSA, 2009 for the call for proposals of the ESF with the highest number of applicants in the Czech Republic).

\subsection{Data Processing}

For the purpose of the research, we have merged the results from the survey with the data about the financial statements of firms. Tab. 1 shows the situation of support in firms. Table 2 depicts organisational changes in firms.

Tab. 2 - Have you changed organisational structure within the last three years? Source: survey, own calculations

\begin{tabular}{|c|c|c|}
\hline & Frequency & Percent \\
\hline Once & 308 & 18,5 \\
\hline More than once & 154 & 9,2 \\
\hline No & 1205 & 72,3 \\
\hline Total & 1667 & 100,0 \\
\hline
\end{tabular}

The comparison includes firms with and without the European Social Fund assistance. It also includes firms with two different types of support. One type of support is from the grant call for proposals where firms have the possibility to change the human resources systems and organise training by themselves. The system project "Educate Yourself!" supports only training without any support to the change of human resources systems or any other system within a firm. Table 3 describes the situation and the number of firms for each combination of characteristics when applying for the assistance. It enables us to analyse firms according to their behaviour and sort them according to it. 
Tab. 3 - Combination of the two types of the ESF assistance in firms. Source: Survey, own calculations

\begin{tabular}{|c|c|c|c|c|c|}
\hline & & \multicolumn{3}{|c|}{$\begin{array}{l}\text { Applicants for the Labour Office support of } \\
\text { training }\end{array}$} & \multirow{2}{*}{ Total } \\
\hline & & $\begin{array}{l}\text { Yes, sup- } \\
\text { ported }\end{array}$ & Yes, rejected & No & \\
\hline \multirow{3}{*}{$\begin{array}{l}\text { Applicants for } \\
\text { the grant calls } \\
\text { for proposals } \\
\text { for support of } \\
\text { training }\end{array}$} & $\begin{array}{l}\text { Yes, sup- } \\
\text { ported }\end{array}$ & 189 & 13 & 226 & 428 \\
\hline & Yes, rejected & 14 & 9 & 67 & 90 \\
\hline & No & 276 & 14 & 766 & 1056 \\
\hline \multicolumn{2}{|c|}{ Total } & 479 & 36 & 1059 & 1574 \\
\hline
\end{tabular}

The differences test between these two types of support uses both types of firms (The firms with support of grants but without support of the Labour Office and the firms with support of the Labour Office but without grant support). It means that there are 529 firms with just one type of support in the sample, 290 with a support from the Labour Office and 239 from the ESF grant project (see table 2 for details). Thus, it is possible to compare the effects of these two types of support to organisational changes only in this type of grant projects.

Levene's test provides results on the equality of variances. This indicates how to proceed in the independent sample test for the difference in productivity between 2008 and 2011. It includes all firms in the sample. Then, it is possible to get information on means differences between the two groups of firms. We present the Levene's test results in this paper for the consistency of the whole process of estimations of effects of organisational changes and the ESF assistance in firms.

To triangulate estimates of the t-tests, we conduct also analysis of variance to compare means in four groups of firms:

- Firms with both organisational changes and the ESF support;

- Firms with organisational changes, but without the ESF support;

- Firms without organisational changes, but with the ESF support and

- Firms neither with organisational changes nor with the ESF support.

The combination of variables reduces the number of cases because some of the data at either variable is missing. The research includes just complete sets of firms. The analysis excludes any case in which at least one value is missing. For example, the analysis of organisational changes and changes in employment comprises 310 cases.

\section{RESULTS AND DISCUSSION}

The test of influence of organisational changes on the productivity is the next step in the analysis. We have conducted the analysis on the statistical software IBM SPSS 19. According to the review of literature, we would expect that there is a positive influence of organisational changes 
on competitiveness measured as productivity change as well as the European Social Fund assistance effect on the same variable.

The results of the t-test in tables 4 and 5 go in contradiction to theoretical expectations as it does not show statistically significant difference in productivity between the two groups of firms reporting organisational changes or without organisational changes. In both types of firms, the productivity raised. If the firms had changed the organisational structure, the mean of productivity change is higher than in firms without an organisational change. It would be understandable from the point of view that this type of firms made changes to increase productivity, but the difference between these two groups is statistically insignificant.

Tab. 4 - Productivity changes between 2008 and 2011 according to their changes in organisational structure - summary statistics. Source: Survey, CZSO, own calculations

\begin{tabular}{|c|c|c|c|c|c|}
\hline & & $\mathrm{N}$ & Mean & $\begin{array}{c}\text { Std. Devia- } \\
\text { tion }\end{array}$ & $\begin{array}{c}\text { Std. Error } \\
\text { Mean }\end{array}$ \\
\hline $\begin{array}{c}\text { Changes in organisational structure in } \\
\text { firms within last three years } \\
\text { (i.e. 2009-2011) }\end{array}$ & Yes & 138 & .1221 & .04482 & .04482 \\
\cline { 2 - 6 } & No & 172 & .0904 & .02544 & .02544 \\
\hline
\end{tabular}

Tab. - 5 Productivity changes between 2008 and 2011 according to their changes in organisational structure - test statistics. Source: Survey, CZSO, own calculations

\begin{tabular}{|c|c|c|c|c|c|c|c|c|c|}
\hline & \multirow{2}{*}{\multicolumn{2}{|c|}{$\begin{array}{l}\text { Levene's Test } \\
\text { for Equality } \\
\text { of Variances }\end{array}$}} & \multicolumn{7}{|c|}{ t-test for Equality of Means } \\
\hline & & & \multirow[t]{2}{*}{$\mathrm{t}$} & \multirow[t]{2}{*}{ df } & \multirow[t]{2}{*}{$\begin{array}{l}\text { Sig. (2- } \\
\text { tailed) }\end{array}$} & \multirow[t]{2}{*}{$\begin{array}{l}\text { Mean } \\
\text { Diff. }\end{array}$} & \multirow[t]{2}{*}{$\begin{array}{l}\text { Std. } \\
\text { Error } \\
\text { Diff. }\end{array}$} & \multicolumn{2}{|c|}{$\begin{array}{c}95 \% \text { Confidence } \\
\text { Interval of the } \\
\text { Difference }\end{array}$} \\
\hline & F. & Sig. & & & & & & Lower & Upper \\
\hline $\begin{array}{c}\text { Equal vari- } \\
\text { ances not } \\
\text { assumed }\end{array}$ & 4.715 & .031 & .615 & 221.100 & .539 & .03169 & .05154 & -.06988 & .13326 \\
\hline $\begin{array}{c}\text { Equal } \\
\text { variances } \\
\text { assumed }\end{array}$ & & & .645 & 308 & .520 & .03169 & .04917 & -.06506 & .12844 \\
\hline
\end{tabular}

The explanation why the firms do not differ in their productivity change due to the organisational changes derives from the change in employment and definition of our proxy variable for productivity. Mean of employment change in firms without organisational changes is 0,029 in comparison with firms reporting an organisational change, where the mean is 0,165 . The difference is statistically significant. It means that the firms with organisational changes achieved also higher sales. Firms without organisational changes increased their productivity by keeping employment as low as possible. 
From this perspective, there are two approaches how to react to economic downturn and time of austerity. The first group of firms made changes to achieve competitiveness. In our case, firms achieved both higher sales and higher employment. The second group of firms started rationalisation of processes by firing some employees when there were not enough customers' orders. The case of the second group helps to sustain activities when economic problems appear, but it is only a short-term solution which does not provide firm added competitiveness in long-term perspective.

We have also tested whether the type of support has an influence on productivity. We compared grants assistance composed of training and organisational changes with the "Educate yourself!" project where only training was provided to firms. The t-test in productivity between 2008 and 2011 for firms with just one type of support (either grant or Educate yourself!) did not reveal statistically significant differences between means of productivity change in firms with the ESF assistance. Both means are higher for ESF grants or the ESF Educate Yourself programme than in the case of organisational changes. It is 0,1459 or 0,1376 respectively. There were only 15 cases of firms with the support of the Educate yourself programme in the sample. Therefore, it is not possible to make any generalized conclusion on the effectiveness of the type of support.

The following test (see tables 6 and 7 for results) reveals that supported firms had achieved higher productivity growth in comparison with a group of firms without the ESF assistance.

Tab. 6 - Difference in productivity between 2008 and 2011 for firms with support of the ESF - summary statistics. Source: Survey, CZSO, own calculations

\begin{tabular}{|c|c|c|c|c|c|}
\hline \multicolumn{2}{|c|}{} & $\mathrm{N}$ & Mean & Std. Deviation & Std. Error Mean \\
\hline \multirow{2}{*}{$\begin{array}{c}\text { Did a firm get support } \\
\text { from the ESF? }\end{array}$} & Yes & 222 & .1282 & .44728 & .03002 \\
\cline { 2 - 6 } & No & 69 & .0085 & .30377 & .03657 \\
\hline
\end{tabular}

Tab. 7 - Difference in productivity between 2008 and 2011 for firms with support of the ESF - test statistics. Source: Survey, CZSO, own calculations

\begin{tabular}{|c|c|c|c|c|c|c|c|c|c|}
\hline & \multirow{2}{*}{\multicolumn{2}{|c|}{$\begin{array}{l}\text { Levene's } \\
\text { Test for } \\
\text { Equality of } \\
\text { Variances }\end{array}$}} & \multicolumn{7}{|c|}{ t-test for Equality of Means } \\
\hline & & & \multirow[t]{2}{*}{$\mathrm{T}$} & \multirow[t]{2}{*}{ Df } & \multirow[t]{2}{*}{$\begin{array}{l}\text { Sig. (2- } \\
\text { tailed) }\end{array}$} & \multirow[t]{2}{*}{$\begin{array}{c}\text { Mean } \\
\text { Diff. }\end{array}$} & \multirow[t]{2}{*}{$\begin{array}{l}\text { Std. } \\
\text { Error } \\
\text { Diff. }\end{array}$} & \multicolumn{2}{|c|}{$\begin{array}{c}95 \% \text { Confidence } \\
\text { Interval of the } \\
\text { Difference }\end{array}$} \\
\hline & F. & Sig. & & & & & & Lower & Upper \\
\hline $\begin{array}{c}\text { Equal } \\
\text { variances as- } \\
\text { sumed }\end{array}$ & .887 & .347 & 2.077 & 289 & .039 & .11967 & .05761 & .00629 & .23306 \\
\hline $\begin{array}{l}\text { Equal vari- } \\
\text { ances not as- } \\
\text { sumed }\end{array}$ & & & 2.529 & 167.167 & .012 & .11967 & .04731 & .02627 & .21308 \\
\hline
\end{tabular}

The change is caused by faster increase of sales than employment in supported firms. When we take into account positive effects of the ESF projects on employment in firms (see the results 
of the study Potluka et. al., 2013), it is necessary to increase sales with higher dynamics than employment to achieve increase in productivity of labour measured by sales divided by employment.

To triangulate the estimates based on the t-tests, we include also the analysis of the differences among means of all combinations of firms' characteristics (firms with/without a change and with/without support of the ESF) by One-way ANOVA test. This test confirms that there was not statistical difference between groups of firms which witnessed organisational change and firms without any organisational change.

Tab. 8 - ANOVA for difference in productivity between 2008 and 2011 for firms with support of the ESF and organisational change - test statistics

\begin{tabular}{|c|c|c|c|c|c|}
\hline $\begin{array}{c}\text { Analysis of } \\
\text { variance }\end{array}$ & $\begin{array}{c}\text { Sum of } \\
\text { Squares }\end{array}$ & $\mathrm{df}$ & Mean Square & F. & Sig. \\
\hline $\begin{array}{c}\text { Between } \\
\text { Groups }\end{array}$ & .353 & 3 & .118 & .634 & .594 \\
\hline $\begin{array}{c}\text { Within } \\
\text { Groups }\end{array}$ & 56.739 & 306 & .185 & & \\
\hline Total & 57.092 & 309 & & & \\
\hline
\end{tabular}

Notes: ${ }^{*} \mathrm{p}<0.001$; Total number of cases used: $\mathrm{N}=310$ (mean 0.1045), of which Companies with change and a support $(\mathrm{N}=108$; mean 0.1387), Companies with a change and without a support $(\mathrm{N}=30$; mean 0.0625$)$, Companies without a change and with a support $(\mathrm{N}=123 ; 0.1084)$, Companies without a change and without a support $(\mathrm{N}=49 ; 0.0453)$

The test also confirmed that the means of changes in productivity are higher for supported firms than for firms without support no matter whether they witnessed organisational changes. Supported firms could finance salaries of project teams (average size of a grant project is 1.2 employees) and also salaries of trainees. It enabled firms to use own sources to finance another activities. Grants also increased income of firms, although the project budgets are strictly connected with proposed budget chapters and it is not possible to use them freely.

\section{CONCLUSIONS}

The competitiveness of firms is of high importance as the competitiveness of regions and countries is based on it. Our article sheds light on influence of organisational changes in firms on productivity and competitiveness and their support from public budgets.

The findings of this article contribute to the discussion on the importance of the public support for the Czech firms' competitiveness. The collected evidence does not confirm that firms in which management changed organisational structure achieved higher productivity during the economic crisis and thus increased their competitiveness. On the other hand, there is a conclusion that firms supported by the ESF witnessed higher positive productivity development then unsupported firms. 
This dynamics in productivity is caused by several reasons. The first of them is that firms with low capacities do not even have the capacity to apply for a grant or a subsidy. Thus, they keep their position with lower productivity dynamics. Second, it was caused by increase of both sales and employment in supported firms as the unsupported firms had slower development of both employment and sales. Third, financial aid is a low-cost or free capital for supported firms. Organisations have the opportunity to effectively use this aid as it covers part of salaries of trainees and makes part of their own sources free of use for other development activities.

\section{Acknowledgement}

Research funding was provided by the Grant Agency of the Czech Republic (GACR P403/12/P350). The authors thank the Ministry of Labour and Social Affairs of the Czech Republic for kind cooperation in the project "Pilot counterfactual impact evaluation OP HRE, Measure 1.1".

We also highly appreciate valuable comments of two anonymous peer-reviewers.

\section{References}

1. Ariely, D. (2009). Predictably irrational: the bidden forces that shape our decisions. London: HarperCollins.

2. Audretsch, D., Coad, A., \& Segarra, A. (2014). Firm growth and innovation. Small business economics, 43(4), 743 - 749. DOI: 10.1007/s11187-014-9560-x

3. Chandler, A. D. (1962). Strategy and Structure: Chapters in the History of the American Industrial. Cambridge: MIT Press.

4. Cheptea, A., Fontagné, L., \& Zignago, S. (2014). European export performance. Review of World Economics, 150(1), 25-58. http://dx.doi.org/10.1007/s10290-013-0176-z

5. Chromjaková, F., \& Rajnoha, R. (2012). Potentials of information and organisational process improvement through trained office staff. Journal of Competitiveness, 4(1). 69-82, http://dx.doi.org/10.7441/joc.2012.01.06

6. Čonková, M. (2013). Analysis of perceptions of conventional and E-learning education in corporate training. Journal of Competitiveness, 5(4) http://dx.doi.org/10.7441/joc.2013.04.05

7. Corbett, L. M., \& Angell, L. C. (2011). Business excellence in New Zealand: continuous improvement, learning, and change. Total Quality Management \& Business Excellence, 22(7), 755-772. DOI:10.1080/14783363.2011.585782

8. Czech Statistical Office. (2014). Organizačni struktura NH [on-line]. Retrieved December 22, 2014, from http://www.czso.cz/csu/2014edicniplan.nsf/t/A9004D58DC/ \$File/3202031426.pdf

9. Daft, R. L. (2010). Organisation theory and design. Andover: South-Western/Cengage Learning.

10. Davis, G. F., \& Marquis, C. (2005). Prospects for organization theory in the early twentyfirst century: Institutional fields and mechanisms. Organization Science, 16(4), 332-343. http:// dx.doi.org/10.1287/orsc.1050.0137

11. Delgado, M., Ketels, C., Porter, M. E., \& Stern, S. (2012). The determinants of national competitiveness, NBER working paper 18249. Retrieved May 22, 2013, from http://www. nber.org/papers/w18249 
12. Dobson, P. W., \& Piga, C. A. (2013). The Impact of Mergers on Fares Structure: Evidence from European Low-Cost Airlines. Economic Inquiry, 51(2), 1196-1217. DOI: 10.1111/j.14657295.2011.00392.x

13. European Commision. (2015). Total allocations of Cohesion Policy 2014-2020. Retrieved May 4, 2015, from: http://ec.europa.eu/regional_policy/en/funding/available-budget/

14. Gulski, B. (2011). Knowledge-management styles and changes in enterprise competitiveness. Organization and Management, (148), 67. http://dx.doi.org/10.2478/v10166011-0004-4

15. Hassard, J., Wolfram Cox, J., \& Rowlinson, M. (2013). Where Are the Old Theories of Organization? Prospects for Retrospection in Organization Theory. Academy Of Management Review, 38(2), 309-313. DOI: 10.5465/amr.2012.0100

16. Hendriks, P. H. J. (2006). Organisational Structure. In Encyclopedia of Knowledge Management (D. Schwartz, pp. 749-756), Hershey: Idea Group Reference.

17. Horňáček, J., \& Zelenková, I. (2014). Employers’ Requirements on Labour Force in the South Moravian Region. Journal of Competitiveness, 6 (4), 63-79. http://dx.doi.org/10.7441/ joc.2014.04.05

18. Huang, F., \& Rice, J. (2013). Does open innovation work better in regional clusters? Australasian Journal of Regional Studies, 19(1), 85-120.

19. Hudrlíková, L., \& Vltavská, K. (2013) Competitiveness and Labour Productivity in Context of Composite Indicators. Statistika, 93 (4), 37 - 45.

20. Huggins, R., Izushi, H., Prokop, D., \& Thompson, P. (2014). Regional competitiveness, economic growth and stages of development. Proceedings of Rijeka Faculty of Economics, Journal of Economics and Business, 32(2), 255-283.

21. Iordan, M., Grigorescu, A., \& Chilian, M. N. (2012). Competitiveness -productivity, sustainable development. Valabian Journal of Economic Studies, 3(4), 103-109.

22. Jensen, P. D. Ø., \& Petersen, B. (2014). Value creation logics and internationalization of service firms. International Marketing Review, 31(6), 557-575. http://dx.doi.org/10.1108/IMR09-2013-0187

23. Jones, C., \& Leishman, C. (2006) Spatial Dynamics and the Housing Market: An Interurban Perspective. Urban Studies, 43, 1041 - 1059, DOI: 10.1080/00420980600711316

24. Jungwirth, C., \& Müller, E. F. (2014). Comparing top-down and bottom-up cluster initiatives from a principal-agent perspective: What we can learn for designing governance regimes. Schmalenbach Business Review (SBR), 66(3), 357-381.

25. Kates, A., \& Galbraith, J. R. (2007). Designing Your Organisation: Using the STAR Model to Solve 5 Critical Design Challenges. Hoboken: Jossey-Bass.

26. Martins, B., \& Solé, F. (2013). Roles-purpose-and-culture misalignments: A setback to bottom-up SME clusters. Journal of Knowledge Management, 17(4), 598-616. http://dx.doi. org/10.1108/JKM-03-2013-0122

27. McDonald, S. (2014). Social responsibility clusters arising from social partnerships. Social Responsibility Journal, 10(2), 331-347. http://dx.doi.org/10.1108/SRJ-12-2012-0152 
28. McLean, G. (2005). Organization Development: Principles, Processes, Performance. Williston: Berrett-Koehler Publishers.

29. Micic, V., Veselinovic, P., \& Miletic, D. (2014). Specialization and competitiveness of the industry in the CEE countries. Actual Problems in Economics, (151), 120-128.

30. Miles, R., \& Snow, C. (2003). Organizational Strategy, Structure, and Process. Palo Alto: Stanford University Press.

31. Mintzberg, H. (1980) Structure in 5's: A Synthesis of the Research on Organisation Design. Management Science. March 1980, 26 (3), 322-341, http://dx.doi.org/10.1287/mnsc.26.3.322

32. Mishra, P., \& Jaiswal, N. (2012). Mergers, acquisitions and export competitiveness: Experience of Indian manufacturing sector. Journal of Competitiveness, 4(1). 3-19, DOI: 10.7441/joc.2012.01.01

33. MLSA. (2009). Výzva k predkládání grantových projektui OP LZZ, c. 35 [on-line]. Retrieved May 22, 2015, from http://www.esfcr.cz/file/7367/

34. MLSA. (2011). Operational programme Human Resources and Employment [on-line]. Retrieved March 10, 2012 from http://www.esfcr.cz/file/4976/

35. Perrow, C. (1973). The Short and Glorious History of Organizational Theory. Organizational Dynamics, 2(1), 2-15.

36. Porter, M. (2008). On Competition: Updated and Expanded Edition. Boston: Harvard Business School Publishing.

37. Potluka, O., Brůha, J., Špacek, M. \& Vrbová, L. (2013). Pilotní counterfactual impact evaluation OP LZZ, oblast podpory 1.1, Př́loha 1: Dopady OP LZZ na zaměstnanost ve firmách [on-line]. Retrieved April 3, 2015 from http://www.esfcr.cz/file/8798

38. Rajnoha, R., \& Lorincová, S. (2015). Strategic Management of Business Performance Based on Innovations and Information Support in Specific Conditions of Slovakia. Journal of Competitiveness, 7(1), 3-21. http://dx.doi.org /10.7441/joc.2015.01.01

39. Ramezan, M., Mohammad, E. S., \& Hassan Rahimian, K. B. (2013). Organizational change capacity and organizational performance. Journal of Knowledge Based Innovation in China, 5(3), 188-212. http://dx.doi.org/10.1108/JKIC-07-2013-0012

40. Robbins, S. (1990). Organization theory: structure, design, and applications. Englewood Cliffs: Prentice-Hall International.

41. Saha, N., Jirčíková, E., \& Bialic-Davendra, M. (2011). The power of clustering and HRM as a source of competitive advantage: Evidence from clusters from Poland, Slovakia, the Czech Republic, India and developed countries. Journal of Competitiveness, 3(4), 87-103.

42. Šebestová, J. (2010). Advantage of cooperative strategies - analysis of their application in health care services. Journal of Competitiveness, 2(1), 98-108.

43. Sherman, H., Rowley, D. J., \& Armandi, B. R. (2007). Developing a strategic profile: the pre-planning phase of strategic management. Business Strategy Series, 8 (3), 162-171, http:// dx.doi.org/10.1108/17515630710684150 
44. Shirokova, G., Berezinets, I., \& Shatalov, A. (2014). Organisational change and firm growth in emerging economies. Journal for East European Management Studies, 19(2), 185-212.

45. Sopelana, A., Kunc, M., \& Hernáez, O. R. (2014). Towards a dynamic model of organisational flexibility. Systemic Practice and Action Research, 27(2), 165-183. http://dx.doi. org/10.1007/s11213-012-9274-4

46. Stojcic, N., Hashi, I., \& Telhaj, S. (2013). Restructuring and Competitiveness: Empirical Evidence on Firm Behavior in New EU Member States and Candidate Countries. Eastern European Economics, 51(4), 84-107.

47. Surdu, G., \& Potecea, V. (2012). Organizational change - different approaches. Romanian Economic and Business Review, 7(4), 70-76.

48. Triguero, A., Córcoles, D., \& Cuerva, M. (2014). Persistence of innovation and firm's growth: evidence from a panel of SME and large Spanish manufacturing firms. Small business economics, 43(4), 787 - 804. DOI: 10.1007/s11187-014-9562-8

49. Wilhelm, P. G., \& Wilhelm, J. P. (2011). Gender empowerment, global competitiveness, economic freedom and wealth: Validation studies and implications for sustainable policy. Competition Forum, 9(2), 406-412.

50. World Economic Forum. 2013 - 2014. The Global Competitiveness Report. [on-line]. Retrieved April 3, 2014, from http://www.weforum.org/reports/global-competitiveness-report-20132014.

\section{Contact information}

Ing. Felipe Martinez, Ph.D.

University of Economics in Prague, Department of Management

W. Churchill Sq. 4, Prague 3 - Žǐ̌kov, 130 67, Czech Republic

Email:felipe.martinez@vse.cz.

Ing. Oto Potluka, Ph.D.

University of Economics in Prague, Department of Management

W. Churchill Sq. 4, Prague 3 - Žǐ̌kov, 130 67, Crech Republic

Email:potluka@vse.cr. 